\title{
I Didn't Know Aiiieeeee, But It Knew Me
}

\author{
By Adrienne Su
}

Of the aunts I had met, only one went by Ayi, so there was no need to number my Ayis.

When I splattered cheesy macaroni on a library book, my mother cried, "Ai-ya!"

Is it worse to see no Asians in a movie, or to see one with a single line: "Aiiieeeee"?

Avoidance failed. No tickee, no laundly. Look at these. She had almond eyes. Ah-so.

All the martial arts were called karate. A human could almost fly: Hai-ya!

Other aunts dwelled in forbidden country. How would it be, to know five Ayis?

To become a writer, I studied Chinese as if English could not contain "ai-ya."

Adrienne Su is the author of four books of poems, Middle Kingdom (Alice James Books, 1997), Sanctuary (Manic D Press, 2006), Having None of It (Manic D, 2009), and Living Quarters (Manic D, 2015). Recipient of a National Endowment for the Arts fellowship, she is poet-in-residence at Dickinson College, where she has taught creative writing since 2000. A native of Atlanta, Georgia, Su has an AB from Harvard and an MFA from the University of Virginia. She has held residencies at The MacDowell Colony, Yaddo, the Virginia Center for Creative Arts, and the Fine Arts Work Center in Provincetown, and was a 2019 grantee of the Money for Women/Barbara Deming Fund. Her poems appear in many anthologies, including The Norton Introduction to Literature, Asian-American Poetry: The Next Generation, The Hungry Ear: Poems of Food and Drink, Vinegar \&amp, Char: Verse from the Southern Foodways Alliance, Children of Grass: A Portrait of American Poetry, and four volumes of Best American Poetry (2000, 2013, 2016, 2018). Her fifth collection of poems, Peach State, which focuses on Chinese Americans in Atlanta, largely during the 1970 s and 1980 s, with food as a central metaphor will be published by Pitt in 2021. Poems from this new book have appeared in journals including 32 Poems, The American Journal of Poetry, Bennington Review, New England Review, The New Yorker, Poetry, and the Academy of American Poets; Poem-a-Day series. Some of them, as well as other poems and assorted prose, can be found at adriennesu.ink.

ISSN: 2154-2171 
I never learned how to swear in Chinese.

Instead, I pretended to die: "Aiiieeeee!"

The International aisle of my grocery

had a sauce resembling neon wine, Ah-So.

A white man at a party tried to correct me.

$\mathrm{Su}$, he said, is really Hsu. Oh, right. Hai-ya! 